\title{
Bearing capacity improvement of soft soil subgrade layer with Bio Stabilized Bacillus Subtilis
}

\author{
Hasriana $^{1, *}$, Lawalenna Samang ${ }^{2,}$ Tri Harianto ${ }^{2}$, M.Natsir Djide ${ }^{3,}$, \\ ${ }^{1}$ Hasanuddin University, Doctoral Program of Civil Engineering, Makassar, Indonesia \\ ${ }^{2}$ Hasanuddin University, Department of Civil Engineering, Makassar, Indonesia \\ ${ }^{3}$ Hasanuddin University, Department of Farmacy, Makassar, Indonesia
}

\begin{abstract}
The problem that is often faced in a road construction is a soil subgrade (soft soil). If the subgrade has a low bearing capacity, causing the soil to decrease greatly, so the road construction will quickly be damaged. Method to overcome the problem is bio stabilization with bacteria utilization. The purpose of this research is to know the bearing capacity improvement of soft soil as subgrade layer with bacteria solution of bacillus subtilis. Tests include soil physical and mechanical properties, compaction parameters and CBR tests. This test is based on ASTM for each test. Variations in addition of bacterial solution were $2 \%, 4 \%, 6 \%$, $8 \%$ and $10 \%$ of dry soil weight with 7 days curing time. The results showed that the maximum value of CBR of soft soil was found at $39 \%$ on $6 \%$ bacterial solution. Increased CBR value from $2.8 \%$ to $39 \%$ or 13 times than untreated soil. This shows the use of bacterial concentration solution on soft soil significantly increases the bearing capacity.
\end{abstract}

\section{Introduction}

In roadway planning, the bearing capacity of the subgrade strongly affects the thickness of the pavement, the higher bearing capacity of subgrade soil, then thickness of pavement becomes thinner to withstand the traffic load. Bearing capacity of subgrade is influenced by soil type, density, water content, and others. If a soil in the field is highly loose or very susceptible to distress and has an inconsistent index of consistency for a development project, then the soil should be improvement to meet the technical requirements. Soil stabilization using bio method with bacillus subtilis bacteria is believed to improve soil characteristics by increasing the bearing capacity of foundation soil, reducing compressibility and permeability, and reducing variation in volume change. The purpose of this research is to know the effect of bacterial addition on soft soil to increase the bearing capacity of the subgrade layer. The advantage of bacillus subtilis bacteria can reduce soil and environment pollution.

Efforts to improve soil properties has large swelling properties have been largely undertaken with soil stabilization methods, including stabilization using environmentally

${ }^{*}$ Corresponding author: hasrianahasan99@yahoo.com 
unfriendly grouting methods which are usually suspense (cement, cement-clay, pozzolan, bentonite, etc.) or emulsions (Asphalt, etc.) [1]. Therefore we are looking for an alternative bio-stabilization method that is environmentally friendly, that is by utilization of microorganisms derived from bacteria because it can produce calcite/calcium carbonate crystals that can change the grain behavior. Various studies have been done before, among others, Bio-Mediated Soil Improvement: Cementation of Unsaturated Sample. This study uses Bio-Mediated Calcit Precipitation. As a soil improvement material. Further experimental Biogrouting Stabilization on Marine Sandy Clay Soil [2]. In this study presents an application that is used to increase the bearing capacity of the soil by means of stabilization. The results showed that urease catalyzing conversion of urea to ammonium and carbonate produced precipitates with calcium as calcium carbonate crystals [3]. These crystals form a bond between the sand grains increasing the strength and stiffness of the sand. The remaining ammonium chloride is extracted and removed. Soil remediation was introduced in this study to increase soil's carrying capacity as land stabilization safely and environmentally friendly.

Bacteria are microscopic organisms has $1.25 \mu \mathrm{m}$ average diameter. Grows at a maximum temperature of $25-75^{\circ} \mathrm{C}$, can be found in air, water, soil, animal fur, and carcasses, optimum $\mathrm{pH}$ grows $5.5-8.5$ [4], bacterial size is microscopic meaning can be seen using a microscope. Active bacteria move in humid conditions. In the state of lack of water, bacteria will be inactive and can even cause death. Micro-organisms are bred by inoculating microorganisms into a new medium. The technique of inoculation used is scratching technique, with previous dilution done before the results obtained colony of pure culture. After incubation in the aerobic state for 24 hours. The culture medium used consisted of nutrient jelly and nutrient broth (NB). The role of bacteria in stabilizing the soil at the time of precipitation of calcium carbonate. The results indicate that bacteria bacillus subtilis showed that bacteria that can breed with temperature in Indonesia and produce calcite/ crystal most come from Papua region [5].

\section{Material and method}

The material used in this study is soft soil from Takalar District, Conventional soil sampling using crowbar and shovel, then the sample of soil is placed in the sample sack and to get the original water content then wrapped with plastic. Some of the steps that will be done are as following; first, undertake a preliminary literature review and preliminary survey to identify the problem and identification of sampling sites; second, do a preliminary test of samples that have been taken to know soft soil characteristics. Labratorium test to know physical properties including moisture content, consistency limits, and specific grafity, while mechanical properties test include compaction test and (CBR).

Table 1. Standard Methode of physical properties testing

\begin{tabular}{|l|l|}
\hline Standard Tests & Standard Method \\
\hline Water content test & ASTM D 2216-71 \\
\hline Specific grafity test & SNI 03-1964-2008 \\
\hline Liquid limit test & SNI 03-1967-1990 \\
\hline Plastic limit test & SNI 03-1966-1990 \\
\hline Sieve analysis test & SNI 03-1968-1990 \\
\hline Compaction test & SNI 03-1742-1989 \\
\hline Uncinfined compression test & SNI 03-6887-2002 \\
\hline Hydrometer test & SNI 03-3423-1994 \\
\hline
\end{tabular}




\subsection{Bacterial growth test}

Growth tests were conducted to determine the growth properties of a bacterial species through a growth curve marked by turbidity in liquid medium with the help of shake and incubator.

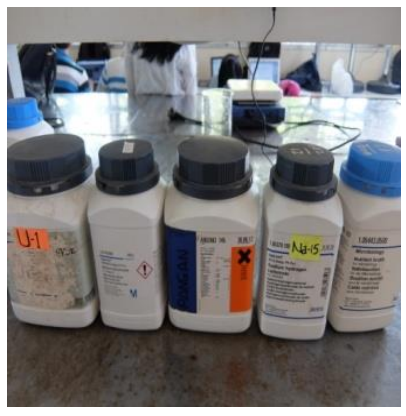

(a)

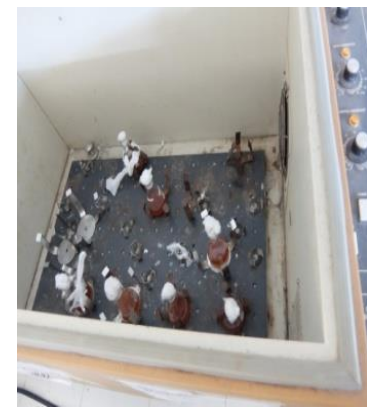

(b)

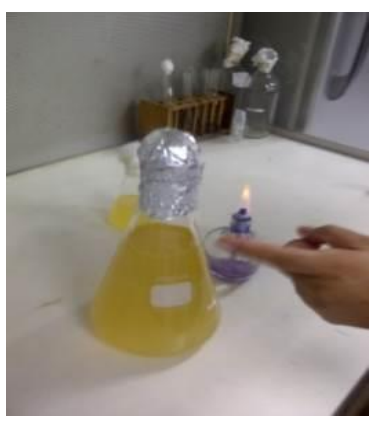

(c)

Fig.1. a) Nutritive ingredients, b). Autoclave tool, and c) Bacterial isolates

Bacterial activation of bacillus subtilis on medium B4 (1 liter of water mixed with $20 \mathrm{~g}$ urea, $3 \mathrm{~g}$ Nutrient Broth, 2,12g NaHCO3, 4, $1 \mathrm{~g} \mathrm{CaCl} 2.2 \mathrm{H} 2 \mathrm{O}, 10 \mathrm{~g} \mathrm{NH} 4 \mathrm{CI}$, and $\mathrm{H} 2 \mathrm{O}$ (Figure 1a). After that, inserted into Autoclave with temperature $121^{\circ} \mathrm{C}$ in 15 minute on 1 atm as in Figure 1b, after cold B4 medium was done bacterial inoculation process that mixing bacteria isolate into medium and grown room shaker for 3 days for mixing on soft soil (Figure 1c).

\subsection{Test of soil physical properties}

CBR measurements in this study were carried out by mixing the soft soil with water that matched the optimum moisture content of the Proctor compaction result and mixed with $2 \%, 4 \%, 6 \%, 8 \%$ and $10 \%$ bacteria solution, for the test after 7 days cured.

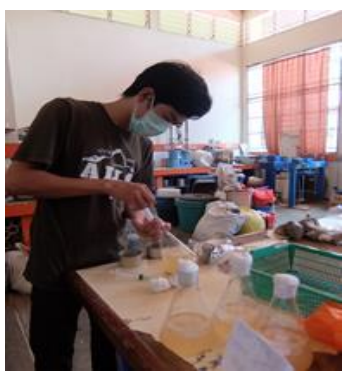

(a)

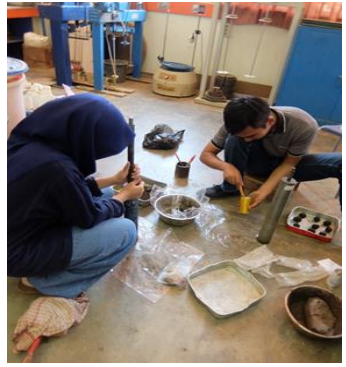

(b)

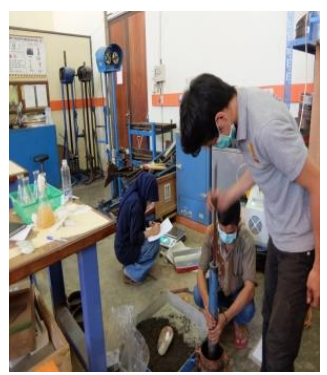

(c)

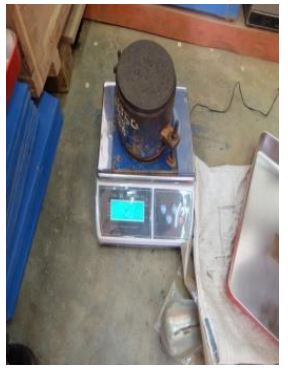

(d)

Fig. 2. Tests procedure: a) mixing the soil with bacteria , b) making of soil samples, c) compaction process, d) Weighing the soil samples 


\section{Result and discussion}

\subsection{Physical Properties of Soft Soil}

Visually observed, soft clay soil in Takalar Regency has black ash color, hard texture so it is not easy to squeeze on dry conditions, whereas if exposed to water, the soil becomes slippery and sticky in hand, easy to mold and plastic impressed. From the results of research in the laboratory as follows.

Table 2. Physical properties of soft soil

\begin{tabular}{|l|c|}
\hline Soil Properties & Values \\
\hline Water content (\%) & 78,12 \\
\hline Specific gravity & 2,68 \\
\hline Liquid limit (\%) & 67,89 \\
\hline Plastic limit (\%) & 30,80 \\
\hline Plasticity index (\%) & 37,08 \\
\hline AASTHO soil classification & $\mathrm{A}-7-5$ \\
\hline USCS Soil classification & $\mathrm{CH}$ \\
\hline \% Passing \# 200 & 95,76 \\
\hline Optimum moisture conten $(\%)$ & 26,5 \\
\hline Maximum dry density (ton $\left./ \mathrm{m}^{3}\right)$ & 1,48 \\
\hline CBR (\%) & 2,8 \\
\hline
\end{tabular}

After conducting the research, has an initial moisture content of $78.12 \%$. Proctor standard compaction test results obtained optimum water content of $26.5 \%$ with a dry volume weight $(\gamma \mathrm{d})$ of $1.48 \mathrm{gr} / \mathrm{cm}^{3}$. Soft soil weight $2.68 \mathrm{gr} / \mathrm{cm}^{3}$. Based on Atterberg limit test of liquid limit of $67.89 \%$, plastic limit of $37.08 \%$, Liquid limit greater than $50 \%$ is one of the common characteristics possessed by soft soils. The results of soil grain size distribution test, it was found that $95.76 \%$ passed sieve No.200 with plasticity index of $37.08 \%$, so it was concluded that according to USCS classification system, classified as fine-grained soil and classified into $\mathrm{CH}$ type that is clay with high plasticity. According to the AASHTO classification system the soil samples are included in the group A-7-5 which is a clay soil with a moderate to bad, since the grain of soil sample passes sieve No.200 \pm $35 \%$ and plastic index $\exists 30 \%$

\subsection{CBR value of soft soil}

CBR test results were performed on soft soil stabilized with variation of bacterial solution of bacillus subtilis and 7 days treatment.

Based on CBR value results that untreated soft soil was $2.8 \%$. The maximum of CBR value on addition of $6 \%$ bacteria. In addition of $2 \%$ bacteria, CBR value of the of $23,67 \%$ with 7 day curing, while addition bacteria of $4 \%$ produce the soil CBR value of $35,54 \%$. Subsequently, in addition of $6 \%$ bacteria produce the soil CBR value of $39 \%$. In addition on the $8 \%$ produce CBR value of $34 \%$, and addition of $10 \%$ bacteria $10 \%$ produce CBR value of $30 \%$. Test results can be interpreted that untreated soft soil has low CBR value and very 
soft soil. These results explain that with increasing curing time and optimum condition of bacteria addition (6\%), the CBR value if soil has greater (Figure $4 b$ ).

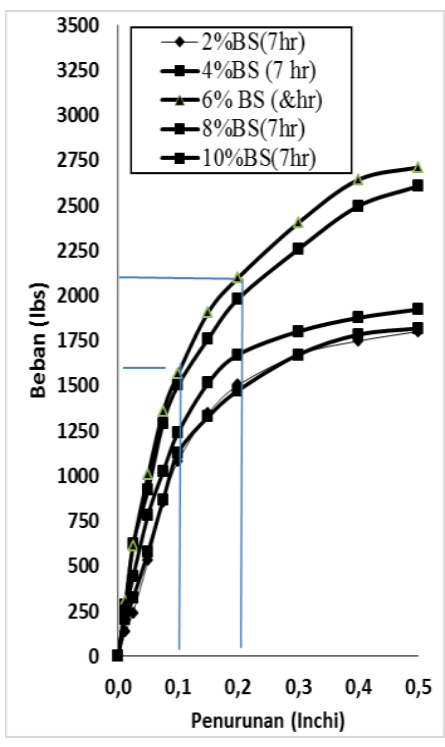

(a)

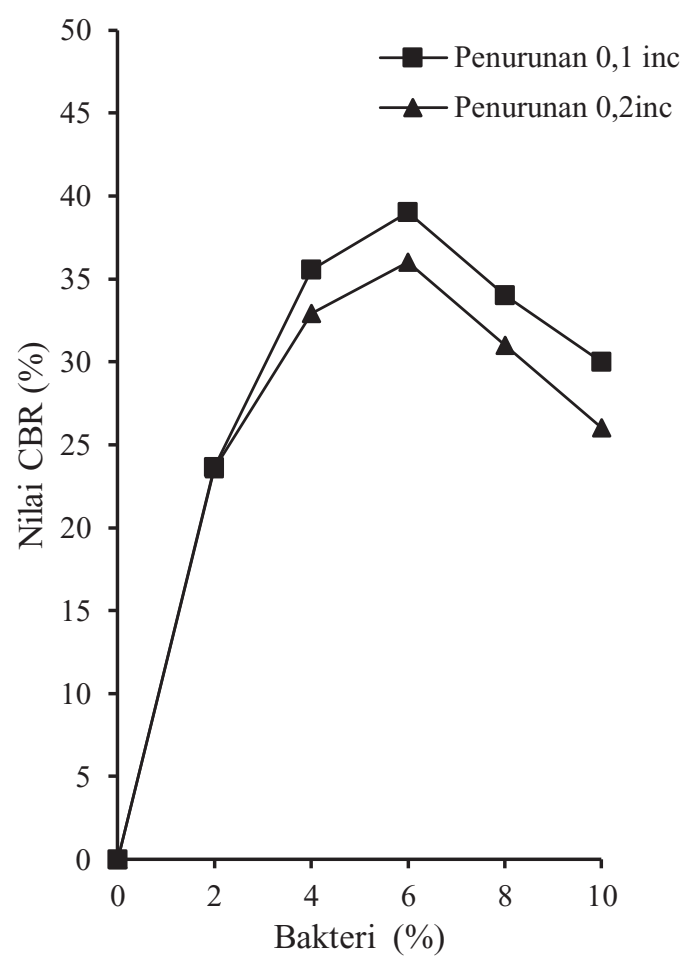

(b)

Fig. 3. a. The relationship between loading and settlement on addition of bacterial solution

b. The relationship between bacterial addition and CBR value

\section{Conclusion}

Based on laboratory test results obtained that soft soil has an initial moisture content of $78.12 \%$. Standard Proctor compaction test obtained optimum water content of $26.5 \%$ with a dry volume weight ( $\square$ d) of $1.48 \mathrm{gr} / \mathrm{cm}^{3}$. Based on Atterberg limit test, the liquid limit of $67.89 \%$ and plastic limit of $30.80 \%$. The liquid limit greater than $50 \%$ is one of the common characteristics of soft soil, the index plasticity value of $37.08 \%$, the soil is very sensitive to surrounding water. Testing of soil grain size distribution, it was found that $95,76 \%$ passed sieve No.200 with plastic index $37,08 \%$, so concluded according to USCS classification system, classified as fine grained soil and classified into $\mathrm{CH}$ type that is clay with high plasticity. According to the AASHTO classification system the soil samples are included in the A-7-5 clusters, which are clays with moderate to poor grades, since the grain of the soil sample passes the sieve\#200 $\square 35 \%$ and the plastic index is $\square 30 \%$. The optimum composition of soft soil stabilization with $6 \%$ bacteria addition and 7 day curing obtained CBR value 39\%. From the test results explain that maximum condition of $6 \%$ bacteria producing CBR value of $39 \%$. In soft soil occurs biodegradation process by bacteri bacillus subtilis. Urea, $\mathrm{CO}\left(\mathrm{NH}_{2}\right)_{2}$ reacts with calcium through an intermediate medium 
produced by bacteria to form ammonium which is a cation so that it can be bonded by $\mathrm{OH}$ and calcium carbonate $\left(\mathrm{CaCO}_{3}\right)$ that precipitates and causes the soil to become hard.

\section{References}

1. Takaendengan P,P, S. Monintja, J.H.Tieoh, J.R.Sumampouw. Pengaruh Stabilisasi Semen Terhadap Swelling Lempung Ekspansif, Jurnal Sipil Statis.Vol1.No 8. Mei (2013).

2. Harianto T, S.Hamzah, Fadliah, WalennaPuspita ,Biogrouting Stabilization on Marine Sandy Clay Soil International Conference on Asian ad pacific Coasts, (2013).

3. Van Paassen, LA. Biogrout ground improvement by micribial induced carbonate precipitation. Delft University of Technology, pp 202. (2009).

4. Buchanan, R.E., and N.E. Gibbons, Bergey's manual of determinative bacteriologi, $8^{\text {th }}$ ed. Williams and Wilkins Co., Baltimore, Maryland Dejong,J (2009). Microbially induced Cementation to Control Sand Response to Undrained Shear. Journal Of Geotechnical and Geoenvironmental. (1975).

5. Lisdiyanti P. Bacterial carbonate precipitation for biogrouting, Prosiding Simposium Nasional Ekohidrologi, PP 219-232. (2011).

6. Hardiyatmo, C. H.Mekanika Tanah 1, Gadjah Mada University Press, Jakarta.

7. Keyka A. Hamed.(2011). Electro- Biogrouting abd Its challenges, Int.J. Electrochem. Sci., 720121196 - 1204. (2010)

8. Hasriana, dkk. Strength Characteristic of Soft Soil with Bacteria Activation, $10^{\text {th }}$ International Symposium on Lowland Technology September 15-17, 2016 at Mangalore, India. (2016).

9. Hasriana, dkk. Pengaruh masa pertumbuhan bakteri bacillus subtilis terhadap peningkatan kuat tekan tanah lunak, KNPTS 2016,. ITB Bandung. (2016). 